\title{
RELATIONSHIP BETWEEN COMMUNICATION SATISFACTION AND ORGANIZATIONAL COMMITMENT IN THREE GUATEMALAN ORGANIZATIONS
}

Federico Varona, Ph.D.

Department of Communication Studies

San Jose State University

One Washington Square

San Jose, CA 95192-0112

fvarona@sjsu.edu

Phone: (408) 924-5392

Fax: (408) 924-5396

Published in:

Varona, Federico. (1996). Relationship between Communication Satisfaction and Organizational Commitment in Three Guatemalan Organizations. The Lournal of Business Communication, 33, 2: 111-140. 


\begin{abstract}
The main purpose of this study was to examine the relationship between organizational communication satisfaction and organizational commitment in three Guatemalan organizations. Data were collected using three questionnaires: the C. W. Downs' (1990) Communication Audit Questionnaire (CAQ), the Mowday, Porter, \& Steers' (1979) Organizational Commitment Questionnaire (OCQ), and the Cook \& Wall's (1980) Organizational Commitment Instrument (OCI). Results indicated that first, there was an explicit positive relationship between communication satisfaction and employees' organizational commitment. Second, school teachers were significantly more satisfied with the communication practices and more committed to their organization than were the employees of the other two organizations (a hospital and a food factory). Third, supervisors were significantly more satisfied than were subordinates with overall communication practices. Fourth, employees with more tenure were significantly more committed to their organizations. Fifth, the three factor solution for the Cook \& Wall's OCI did not emerge, as it had been theorized by its authors, from this sample. A two factor solution for the Mowday, Porter \& Steers's OCQ emerged as appropriate for the Guatemalan sample. Finally, the conflicting findings on the internal reliability and factor analysis of one of the commitment instruments used in this study between the studies conducted in the USA and this one conducted in Guatemala raise several important issues on the use of research instruments in cross-cultural studies.
\end{abstract}


Over the past two decades, the constructs of Communication Satisfaction and Organizational Commitment have been important variables of interest to organizational communication researchers (Clampitt \& C.W. Downs,1993; Putti, Aryee, \& Phua, 1990; Clampitt \& C. W. Downs, 1987; Buchanan, 1974; Mowday, Porter \& Steers, 1982; Reichers, 1985; Cook \& Wall, 1980) and yet few studies have focused directly on the relationship between these two organizational variables.

The main purpose of this study was to examine this relationship in Guatemalan organizations. In addition, other issues were investigated: (a) the differences and similarities in employees' communication satisfaction and organizational commitment; (b) the impact of tenure and position on communication satisfaction and organizational commitment; and (c) the factor solution of the two organizational commitment instruments for the Guatemalan sample.

A review of the literature reveals that there is a lack of research on organizational communication satisfaction and its relationship with other organizational variables in foreign countries, especially in Latin America (Shuter \& Wiseman, 1994). Therefore, this pioneer study represents a significant contribution to the development of multinational organizational communication research and expands it into another country, namely, Guatemala.

\section{COMMUNICATION SATISFACTION}

The Communication Satisfaction construct, operationalized by C. W. Downs \& Hazen in 1977, has become a successful research stream in organizational communication. Since then, more than thirty studies have been completed using the "Communication Satisfaction Questionnaire" (Clampitt \& C. W. Downs, 1987; Clampitt \& C. W. Downs, 1993) and an 
expanded form of it called "Communication Audit Questionnaire" (C. W. Downs, 1990). Some of these studies have been conducted in foreign countries: Nigeria (Kio, 1979); Mexico (Alum, 1982); China (Lee, 1989); Guatemala (Varona 1988, Varona 1993); Australia (Downs, 1991). C. W. Downs \& Hazen (1977) explored the multidimensionality of communication satisfaction using an original questionnaire called "Communication Satisfaction Questionnaire". The eight factors that resulted from this analysis were described by C. W. Downs \& Hazen , 1977; and C. W. Downs, 1988, as follows:

Organizational Perspective deals with the broadest kinds of information about the organization as a whole. It includes items on notifications about changes, information about the organization's financial standing, and information about the over-all policies and goals of the organization. Personal Feedback is concerned with the workers' need to know how the are being judged and how their performance is being appraised. Organizational Integration revolves around the degree to which individuals receive information about their immediate environment. Items include the degree of satisfaction with information about departmental plans, the requirements of their job, and some personnel news. Supervisory Communication includes both the upward and downward aspects of communicating with superiors. Three of the principal items are the extent to which superiors are open to ideas, the extent to which supervisors listen and pay attention, and the extent to which superiors and supervisors offer guidance to their employees in solving job-related problems. Communication Climate reflects communication on both the organizational and personal levels. On one hand, it includes items such as the extent to which communication in an organization motivates and stimulates workers to meet organizational goals and the extent to which it makes them identify with the organization. On the 
other, it includes estimates of whether or not people's attitudes toward communicating are healthy in the organization. Horizontal Communication concerns the extent to which coworkers and informal communication is accurate and free flowing. This factor also includes satisfaction with the activeness of the grapevine. Media Quality deals with the extent to which meetings are well-organized, written directives are short and clear, and the degree to which the amount of communication is about right. Subordinate Communication focuses on upward and downward communication with subordinates. Only workers in supervisory positions respond to these items which include subordinate responsiveness to downward communication, and the extent to which subordinates initiate upward communication.

C. W. Downs (1990) expanded this questionnaire by adding two new factors, which were called and described as follows:

Top Management Communication evaluates the communication of top management with organization members. This factor includes items about top management attitudes towards openness to new ideas, caring, and willingness to listen. Interdepartmental Communication deals with the communication that is needed among the different departments of the organization in order to facilitate its efficiency. It includes items about problem solving, teamwork, and communication among managers.

The findings of the studies that have used the Communication Satisfaction Questionnaire indicate (Clampitt \& C. W. Downs, 1993; Clampitt \& C. W. Downs 1987): First, that there are definite areas of greatest and least communication satisfaction. The areas of greatest employee satisfaction are the Supervisory Communication and Subordinate Communication, while the area of least satisfaction tends to be the Personal Feedback factor. Second, there appears to be some 
indication that employees in managerial roles are most satisfied with communication than those who are not. Third, demographic variables provided relatively poor explanations of the level of communication satisfaction (Nicholson, 1980, Clampitt \& Girard, 1993, Varona, 1988). Fourth, communication satisfaction links significantly to job satisfaction (Clampitt \& Girard, 1993; Lee, 1989; Varona, 1988). Personal Feedback, Communication Climate , and Supervisory Communication are the three factors that have had the strongest correlation with job satisfaction (C. W. Downs, 1977; C. W. Downs, Clampitt, \& Pfeiffer, 1988). Finally, research has suggested (Clampitt \& C.W. Downs, 1993) that the link between communication and productivity is more complex than previously assumed.

\section{ORGANIZATIONAL COMMITMENT}

The term of "commitment" has been variously and extensively defined, measured, and researched but it continues to draw criticism for the lack of precision and for concept redundancy (Morrow, 1983; Reichers, 1985).

A review of the literature (Buchanan, 1974; Mowday, Porter \& Steers, 1982; Reichers, 1985) showed that there are at least three distinct approaches to defining commitment. First, the exchange (side-bets) approach views commitment as an outcome of inducement/contribution transactions between the organization and member. Second, the psychological approach defines commitment as an attitude or an orientation toward the organization which links or attaches the identity of the person to the organization. The three components of this orientation consist of (a) identification with the goals and values of the organization, (b) high involvement in it work activities, and (c) a strong desire to maintain membership in the organization (Porter, 
Steers, Mowday, \& Boulian 1974; Steers, 1977). And third, the attributions approach (Reichers, 1985) defines commitment as a binding of the individual to behavioral acts and it occurs when individuals attribute an attitude of commitment to themselves after engaging in behaviors that are volitional, explicit, and irrevocable.

There have been two major attempts to provide a theoretical framework of organizational commitment, in order to develop a more precise and comprehensive construct. The first of these was the multivariate predictive framework which proposed a model that consisted of two parts: (a) the antecedents of commitments, and (b) the outcomes of commitment (Steers, 1977). The most recent research on organizational commitment shows that study designs draw heavily on the multivariate predictive framework (Eisenberg, Monge, \& Miller, 1983, Leiter \& Maslach, 1988, Mottaz, 1988). These studies try to link different organizational variables (involvement in communication networks, interpersonal environment, burnout, pay, promotional opportunities, task characteristics, etc.) to organizational commitment. The second theoretical framework- the multiple commitment framework- proposed by Reichers (1985) suggests that organizational commitment can be accurately understood as a collection of multiple commitments to the various groups that comprise an organization. These multiple identifications with various groups, both inside and outside the organization, constitute multiple commitments. This reconceptualization was designed to integrate the individual's actual experience of commitment with the organizational aspects of the construct. The theoretical framework for this conception is based on an organizational theory that sees organizations as coalitional entities, and as reference groups (Blau \& Scott, 1962; Gouldner, 1957).

An analysis of these two conceptual frameworks (the multivariate predictive model and 
the multiple commitments model) of organizational commitment show that, in reality, these are not two opposite approaches but rather two complementary perspectives that can be integrated. The outcome of this integration provide us with the common and comprehensive theoreticallygrounded framework that is needed to build predictive models of a particular measure of the organizational commitment construct.

\section{RELATIONSHIP BETWEEN COMMUNICATION SATISFACTION AND ORGANIZATIONAL COMMITMENT}

The construct of organizational commitment has been researched extensively over the past two decades. Some of these studies have demonstrated the relationships between commitment and several other organizational variables: (a) absenteeism (Steers, 1977; Larson \& Fukami, 1984); (b) leadership style (Morris \& Sherman 1981); (c) job performance (Mowday, Porter \& Dubin, 1974; Steers, 1977); (d) turnover (Kom, Katerberg \& Hulin, 1979; Angel \& Perry 1981); (e) communication openness (Argyris in Housel \& Warren, 1977); (f) network involvement (Eisenberg, Monge, \& Miller, 1983), (g) participation in decision making (Hall, 1977), (h) amount of feedback received on the job; and (i) socialization strategies of new employees (Buchanan, 1974). In most of these studies the antecedents of commitment have focused primarily on structural, individual, and role-related variables (Mowday, Porter, \& Steers, 1982; Dornstein \& Matalon, 1989). The review of this research stream shows that organizational processes have been ignored as potential determinants of commitment (Putti, Aryee, \& Phua, 1990). One of these organizational processes that has been ignored is member satisfaction with organizational communication practices. In fact, there is a lack of research on the relationship 
between communication satisfaction and organizational commitment. Therefore, the relationship that is believed to exist between these two variables is more implied than demonstrated. Until now few studies have supported a relationship between communication satisfaction and organizational commitment (Putti, Aryee, \& Phua, 1990; Potvin, 1991; Downs, 1991; C. W. Downs et al., 1995).

Putti, Aryee, \& Phua (1990) explored the impact of communication relationship satisfaction on organizational commitment in an engineering company in Singapore. They demonstrated a relationship between communication satisfaction and organizational commitment. The two factors that showed the strongest relationship to organizational commitment were relationship with top management and supervisor, of these the relationship with top management had the highest correlation. Potvin's (1991) study addressed the relationship between communication satisfaction and organizational commitment in three US organizations: a retail organization, a large hospital, and a multi-national high technology organization located in the Dallas/Ft. Worth Metroplex and in Houston, Texas. Potvin concluded that there was a definite positive relationship between communication satisfaction and employees' organizational commitment. The strongest correlations appeared between commitment composites, and Communication Climate and Supervisory Communication. She also concluded that the demographic variables seemed to have no explanatory power with regard to commitment levels.

Downs (1991) studied the relationship between communication satisfaction and organizational commitment in two Australian organizations. She found that a positive relationship existed between communication satisfaction and organizational commitment. She 
also found that the exact relationship between communication dimensions and levels of commitment varied somewhat across organizations. Finally, she discovered that Supervisory Communication, Personal Feedback, and Communication Climate were the strongest communication predictors of organizational commitment.

In a more recent study on cross-cultural comparisons of relationships between organizational commitment and organizational communication, C. W. Downs et al. (1995) compared results obtained in USA, Australian and Guatemalan organizations. The research measures used for this cross-cultural study were: the C. W. Downs' Communication Satisfaction Questionnaire, and the Cook \& Wall's Organizational Commitment Instrument. The findings of this study revealed: (a) that satisfaction with communication factors is significantly related to organizational commitment; (b) satisfaction with Communication Climate had the highest correlations across all countries; (c) the correlations ran generally higher for the Americans than for the Guatemalans and the Australians; (d) Regression analyses revealed that the links between communication and commitment vary considerably and that comparability among sample companies is limited; and (e) the most frequent communication predictors of commitment were Satisfaction with Supervisor Communication, Horizontal Communication, Communication Climate, and Top Management Communication. Satisfaction with Supervisory Communication was a much greater predictor than that of any other factor. On the other hand, some differences were found among the countries. First, satisfaction with Supervisory Communication was a good predictor of commitment for the USA and Australian organizations but not for the Guatemalan organizations. Second, a closer tie existed between communication satisfaction in general, and commitment for the Americans than for the Australians and 
Guatemalans, being the lowest correlations for the Guatemalans. And third, that the correlation between commitment and satisfaction with Supervisory Communication, one of the most important links in the USA and Australia, did not exist in Guatemala.

\section{RESEARCH QUESTIONS}

To accomplish the purpose of this study, as stated in the introduction, the following research questions were formulated: First, what is the relationship between the communication satisfaction factors and the organizational commitment composites and factors? Second, what are the differences and similarities in employees's responses for the communication satisfaction factors and for the organizational commitment composites and factors among the three Guatemalan organizations? Third, what is the impact of tenure (years of service) and position (supervisor vs. subordinates) on the communication satisfaction factors and organizational commitment composites and factors? And fourth, what is the internal reliability and the factor solution for the three research instruments used in this study for the Guatemalan sample?

\section{METHOD}

\section{Subjects}

The sample of 307 subjects was drawn from three different organizations located in Guatemala City, Guatemala. Organization 1 was a private Catholic school for middle class female students. The faculty of 99 members consisted of 96 females and 3 males. A total of 87 out of the 117 employees (74\%) completed the questionnaires . Organization 2 was a private Catholic children' hospital that served children of poor families. A total of 46 out of the 75 
employees (61\%) completed the questionnaires. Organization 3 was a food factory. A total of 177 out of the 400 employees (44\%) completed the questionnaires.

\section{Research Instruments}

The instruments used for this study were: 1) C. W. Downs' (1990) Communication Audit Questionnaire (CAQ); 2) Mowday, Porter \& Steers's (1979) Organizational Commitment Questionnaire (OCQ); and 3) Cook \& Wall's (1980) Organizational Commitment Instrument (OCI).

The Communication Audit Questionnaire (CAQ) is an expansion done by C. W. Downs (1990) of the Communication Satisfaction Questionnaire that was developed by C. W. Downs \& Hazen (1977). The questionnaire was constructed to indicate level of satisfaction of respondents with fifty items using a one-to-seven point scale which ranged between 1="very dissatisfied" and 7="very satisfied". The questionnaire consists of the ten factors defined above and each factor is measured with five items. For the purpose of this study three demographic questions related to tenure, position and work unit were added. A question on the overall level of commitment to the organization (Global Commitment) was also included, using a one-to-seven point scale which ranged between 1="very low" and 7="very high". Several studies support the reliabilities and validities of this instrument (C. W. Downs \& Hazen, 1977; Crino \& White, 1981; Greenbaum, Clampitt, \& Willihnganz, 1988). Although some questions have been raised about the stability of the eight original dimensions, the eight factor solution has been confirmed (Crino \& White, 1981; Clampitt \& Girard, 1987). Other researchers have noted the thoroughness of the construction of this questionnaire (Hecht, 1978, Clampitt \& Girard, 1993).

The Mowday, Porter, \& Steers' Organizational Commitment Questionnaire (OCQ) was 
developed in 1980 and, it is the most frequently used instrument for the measurement of organizational commitment. Responses to the 15-item OCQ are measured on a 7-point Likertlike scale which ranged between $1=$ "strongly disagree" and 7="strongly agree". This questionnaire has achieved acceptable levels of reliability and face validity and, in addition, its convergent and predictive validity were also found to be high (Barge \& Schlueter, 1988). Several studies have reported high levels of internal reliability (Mowday, Porter, \& Steers, 1982; Potvin, 1991; Downs, 1991). No theoretical factor solution has been suggested for this instrument by the authors.

The Cook \& Wall's Organizational Commitment Instrument (OCI) was also developed in 1980 and originally designed for use with British blue collar workers. Three theoretical components of commitment characterized this measure: identification, involvement, and loyalty (Barge \& Schlueter, 1988). The instrument consists of nine items, with three items representing each theoretical component. The responses are based upon a 7-point Likert-like format which ranged between $1=$ "strongly disagree" and 7="strongly agree". The levels of reliability and face validity of this instrument were acceptable, but its convergent and predictive validity were found to be low (Barge \& Schlueter, 1988). Researchers have reported different alpha coefficients for internal reliability: Cook \& Wall (1980), (.79); Potvin (1991), (.83); Downs (1991), (.81).

These three research instruments were selected for this study because they were the most widely used and have achieved acceptable levels of validity and reliability.

\section{Translation of the Instruments}

The translations of the questionnaires from English into Spanish were conducted 
following the procedures used in intercultural research (Johnson \& Tuttle, 1989; Hofstede, 1980; Ady, 1994). First, the questionnaires were carefully translated from their original English versions into Spanish by the author of this study. Second, this translation was reviewed by other professional persons who were fluent in both the English and Spanish languages. Third, a backtranslation of the instruments by a bilingual person was performed. Finally, the back-translation text was compared with the original text, and differences between these two texts were resolved through discussion between translators. The Spanish version of the instruments were rigorously pretested, using a sample of Latin American subjects, in order to establish conceptual/linguistic and functional equivalence before the instruments were administered to the Guatemalan subjects used in this study.

\section{Data Analysis}

Data from the questionnaires were analyzed using the Statistical Package for the Social Sciences (SPSSx) version 4.1. The following statistical procedures were conducted: First, Cronbach Alphas were computed to determine the internal reliability of each of the instruments used in this study. Second, Factor Analyses with the Varimax Rotation were performed to assess the factor solution for each instrument. Third, Pearson Correlations Analyses were also computed using only Organization 3 (Food Factory) sample to determine the relationship between: (a) communication satisfaction factors and Mowday, Porter, \& Steers organizational commitment composite; (b) communication satisfaction factors and the Cook \& Wall organizational commitment composite and each of its commitment factors: Identification, Loyalty, and Involvement; (c) communication satisfaction dimensions and the variables of tenure 
and Global Commitment. Pearson correlations could not be computed for the other two organizations (School and Hospital) because commutation satisfaction data and organizational commitment data were collected separately in these two organizations. Fourth, Stepwise Multiple Regression Analyses were computed for the purpose of prediction of the effect of communication satisfaction factors and composite on commitment composites and factors. Fifth, Paired Tests were conducted to compare supervisors with subordinates on their levels of communication. Sixth, Analyses of Variance (ANOVA) were computed to determine significant differences for the following comparisons: (a) organizations were compared on communication satisfaction factors and commitment composites and factors; (b) tenure was compared on communication satisfaction factors and commitment composites and factors; (c) more committed and less committed were compared on communication satisfaction factors; and (d) more satisfied with communication and less satisfied were compared on commitment composites and factors.

\section{RESULTS}

This section reports the results of the statistical analyses for each of the research questions. First, results on the internal reliability and the factor solution for the three research instruments used in this study. Second, results on the relationship between the communication satisfaction factors and the organizational commitment composites. Third, results on the differences and similarities in employees's responses for the communication satisfaction factors and for the organizational commitment composites among the three Guatemalan organizations. Fourth, results on the impact of tenure (years of service) and position (supervisor vs. 
subordinates) on the communication satisfaction factors and organizational commitment composites and factors are produced.

\section{Internal Reliability and the Factor Solution for the Three Research Instruments Communication Audit Questionnaire (CAQ)}

The Cronbach Alphas obtained for the C. W. Downs' Communication Audit Questionnaire (CAQ) using the entire sample of this study were (.97), and for the factors the Cronbach Alphas ranged from a low of (.64) for the Horizontal Communication factor to a high of (.92) for the Top Management Communication factor. The factor analysis with the Varimax Rotation performed across all the Communication Audit Questionnaire (CAQ) for the sample used in this study confirmed, for the most part, the factor solution proposed by C. W. Downs \& Hazen, 1977, and C. W. Downs, 1990. The new two factors: Top Management Communication and Interdepartmental Communication retained their integrity with this sample.

\section{Cook \& Wall's Organizational Commitment Instrument (OCI)}

The Cronbach Alphas obtained for the Cook \& Wall's Organizational Commitment Instrument (OCI) were: (.55) for the composite (9 items); (.43) for the Involvement factor (3 items); (.33) for the Identification factor (3 items); and only (.09) for the Loyalty factor (3 items). On the other hand, the Cook \& Wall's OCI demonstrated a high convergent validity for this sample. The OCI had a significant $(\mathrm{p}<.001)$ and strong correlation of $(.55)$ with the Mowday, Porter, \& Steers' Organizational Commitment Questionnaire (OCQ) and of (.76) with 
the Commitment Composite. A factor Analysis with the Varimax Rotation was also performed across all of the items from 1 to 9 of the Cook and Wall's OCI simultaneously to uncover any possible underlying commitment factors. The results, revealed that a three factor solution was appropriate. The first factor, which could be labeled "Involvement", contained two of the items (6 and 9) of the theorized Involvement factor, and two more (1 and 5) from the theorized Identification factor. This factor accounted for $26.0 \%$ of the variance. The second factor, which could be named "Lack of Identification", contained three items (8,3 and 2) each of which came from one of the three theorized factors. This factor accounted for $14.9 \%$ of the variance. The third factor, called "Loyalty", retained two of the original items (7 and 4) of the theorized Loyalty factor and accounted for $12.1 \%$ of the variance.

\section{Mowday, Porter, \& Steers' Organizational Commitment Questionnaire (OCQ)}

The Cronbach Alphas obtained for the Mowday, Porter \& Steers' OCQ (15 items) were (.76) which might be considered acceptable. The Factor Analysis with the Varimax Rotation of Mowday, Porter, \& Steers' OCQ yielded a first factor, which could be called Organizational Identification, with 8 items (2,5,6,8,10,13,14 and 15) loading significantly on it and accounting for $28.9 \%$ of the variance. A second factor, named Organizational Loyalty, with five items $(3,7,9,11$ and 12$)$ loading significantly on it, accounted for $12.0 \%$ of the variance. A third factor, with only one item (4) loading significantly on it accounted for $8 \%$ of the variance.

\section{Communication Satisfaction Factors and Composite and Organizational Commitment}

\section{Composites and Factors}


Table 1 reports the Pearson correlations coefficients between communication satisfaction factors and composite, and organizational commitment composites for Organization 3 (Food Factory). The communication satisfaction composite was determined by computing the overall mean of all the communication satisfaction items of the Communication Audit Questionnaire (CAQ). Similarly, the commitment composites were determined by computing: first, the overall mean for all the commitment items combined and second, the overall mean for each of the two Organizational Commitment Questionnaires used in this study. Pearson Correlations could not be computed for the other two organizations (School and Hospital) because communication satisfaction and organizational commitment data were collected separately in these two organizations.

Overall, the correlation between the communication satisfaction composite and overall commitment composite for organization 3 (Food Factory) was significant $(\mathrm{p}<.001)$, moderate and positive (.47). Each of the ten communication satisfaction factors had also significant $(\mathrm{p}<.001)$, moderate and positive relationships with the overall commitment composite ranging from (.30) for Top Management Communication to (.67) for Subordinate Communication

\section{(Table 1).}

The commitment composites, however, correlated differently with the communication satisfaction factors. The Mowday, Porter, \& Steers commitment composite had the strongest correlation with the ten communication factors. The Cook \& Wall composite had the weakest correlation with the ten communication factors. Most of the correlations between each of the three factors (Identification, Loyalty, and Involvement) of the Cook \& Wall's questionnaire and the communication satisfaction factors and composites were not significant and very weak. This 
is the reason why they were not reported in Table 1.

In terms of the relationships between specific communication satisfaction factors and the commitment composites, the correlation analyses showed the following: Overall, the strongest correlations appeared to be between Subordinate Communication and the commitment composites. Specifically, correlations between Subordinate Communication and commitment factors were: (.60) for the Mowday, Porter, \& Steers composite, and (.42) for the Cook \& Wall composite. The second strongest correlation was between Organizational Integration and the commitment composites. Specifically, the correlations between Organizational Integration and commitment composites and factors were .43 for the Mowday, Porter, \& Steers composite, and .27 for the Cook \& Wall composite. The third strongest correlation was between Communication Climate and the commitment composites. Specifically, the (.41) correlation between Organizational Climate and the Mowday, Porter, \& Steers composite. The fourth strongest correlation was between Interdepartmental Communication and commitment composites and factors. Specifically, the correlations between Interdepartmental Communication and commitment composites were: (.41) for the Mowday, Porter, \& Steers composite, and (.24) for the Cook \& Wall composite.

\section{Comparison of Less Satisfied with Communication Versus More Satisfied Employees on}

\section{Commitment Composites for Organization 3 (Food Factory)}

To uncover significant differences between less and more satisfied employees with communication on the commitment composites for Organization 3 (Factory) an Analysis of Variance was computed. For the purpose of this analysis the subjects of the Organization 3 
sample were divided into two groups based on their overall communication satisfaction:

responses 1 to 3, on a scale of 1 to 7 where 1 was "Very dissatisfied" and 7 "Very Satisfied", were categorized as being less satisfied (71 subjects) and responses 5 to 7 were termed as being more satisfied (70 subjects). Thirty six subjects that responded number 4 "Indifferent" were excluded of this analysis.

The results (Table 2) show that the ratings of more satisfied employees with communication were significantly higher ( $<<.01$ or more) than the ratings of less satisfied employees for the Commitment Composite, the Mowday, P orter, \& Steers Composite, the Cook \& Wall Composite, the Cook \& Wall Involvement and Identification factors, and for Global Commitment ( the mean of all the responses to the overall commitment question that was included in the CAQ for this study).

\section{Comparison of Less Committed Versus More Committed Employees on Communication}

\section{Satisfaction Factors and Composite for Entire Sample}

Table 3 shows the results of the Analysis of Variance that was computed to compare less committed and more committed employees with their organization, in order to uncover significant differences on communication satisfaction factors and composite. For the purpose of this analysis the subjects of the entire sample were divided into two groups based on their Global Commitment (the mean of all the responses to the one question included in the CAQ: How would you rate your level of commitment to your current work organization? The scale was 1 to 7, being 1 "Very High" and 7 "Very Low". Responses 1 to 4 were categorized as being less committed (119 subjects) and responses 5 to 7 were termed as being more committed (171 subjects). 
The results show that the ratings of more committed employees with their organizations were significantly higher ( $\mathrm{p}<.05$ or more) than the ratings of less committed employees on all the communication factors and composite, except for Subordinate Communication.

\section{Regression Analyses}

Table 4 reports the results of a Stepwise Multiple Regression that was performed within Organization 3 (Food Factory) and across the entire sample for the purpose of explaining the relationship between communication satisfaction and commitment. In this analysis the CAQ factors and composite were treated as the predictor variables and the commitment composites as the dependent variables. The only CAQ factor that was leaving out in this analysis was the Subordinate Communication factor because the items that make up this factor were answered only by supervisors.

The results presented in Table 4shows that: First, that the Communication Satisfaction Composite was a significant predictor $(\mathrm{p}<.001)$ for all the Commitment composites (Mowday, Porter, \& Steers composite, Cook \& Wall composite, Global Commitment for Organization 3; and Global Commitment for the entire sample). Second, Organizational Integration was the CAQ factor that displayed the most consistency as a significant predictor $(\mathrm{p}<.001)$ of Mowday, Porter, \& Steers composite, Cook \& Wall composite, and Cook \& Wall Identification factor for Organization 3. Third, Horizontal Communication, Organization Integration, and Organizational Perspective were the factors that appeared as significant predictors $(\mathrm{p}<.05$ or more) of the Cook \& Wall composite and factors for Organization 3. Other CAQ factors that appeared as significant predictors $(\mathrm{p}<.001)$ of commitment composites for Organization 3 were: 
Media Quality, Supervisory Communication, Organization Perspective, and

Interdepartment Communication; and for the entire sample: Horizontal Communication and Organizational Perspective.

\section{Comparison of Organizations on Satisfaction and Commitment}

$\underline{\text { Table } 5}$ shows the results of the Analyses of Variance that were computed to compare organizations on communication satisfaction factors. The ratings of school teachers (Organization 1 ) were significantly higher ( $\mathrm{p}<.05$ or more) than the ratings of the employees of the other two organizations (Hospital and Food Factory) on all the Communication Satisfaction factors and composite except for the Subordinate Communication factor.

Moreover, the Scheffé and Student-Newman-Keuls procedures for Post Hoc Multiple Pairwise Comparisons (Norušis, 1993) showed the following results . First, school teachers (Organization 1) rated their level of satisfaction with the communication practices related to Organizational Perspective, Organizational Integration, Horizontal Communication, and Media Quality significantly higher $(\mathrm{p}<.001)$ than employees of the other two organizations (Hospital and Food Factory). Second, school teachers rated their level of satisfaction with communication practices related to Personal Feedback significantly higher $(\mathrm{p}<.05)$ than employees of the hospital. Third, school teachers rated their level of satisfaction with communication practices related to the Top Management Communication factor significantly higher $(\mathrm{p}<.01)$ than employees of the food factory. Finally, the Scheffé procedure for Post Hoc Multiple Pairewise Comparisons (Norušis, 1993) showed that school teachers rated their level of satisfaction with the Communication Satisfaction Composite significantly higher $(\mathrm{p}<.001)$ 
than employees of the other two organizations.

On the other hand, Table 6 presents the results of the Analyses of Variance when organizations were compared on commitment composites and factors. The ratings of school teachers (Organization 1) were significantly higher $(\mathrm{p}<.001)$ than the ratings of the employees of the other two organizations (Hospital and Food Factory) on all the commitment composites except for the Mowday, Porter, \& Steers composite and the Cook \& Wall Loyalty factor.

The Scheffé and Student-Newman-Keuls procedures for Post Hoc Multiple Pairwise Comparisons (Norušis, 1993) showed that school teachers rated their level of organizational commitment significantly higher $(\mathrm{p}<.001)$ than employees of the other two organizations (Hospital and Food Factory) on Commitment Composite, Cook \& Wall Composite, Cook \& Wall Identification factor, Cook \& Wall Involvement factor, and Global Commitment.

\section{Tenure Comparisons}

\section{Comparison of Tenure on Communication Satisfaction Factors}

Table 7 reports the results of the Analyses of Variance when tenure and communication satisfaction factors were compared for the entire sample (the three organizations together) and for each organization separately. For the purpose of this analysis the subjects were divided into four groups according to the time of service in the organization: group 1: fewer than 1 year; group 2:1 to 3 years; group 3: 4 to 6 years; and group 3: more than 6 years.

The results for the entire sample (Table 7) show that, the different groups of tenure were significantly different $(\mathrm{p}<.01$ or more) on their levels of satisfaction on the following communication satisfaction factors: Personal Feedback, Communication Climate, Horizontal 


\section{Communication, Top Management Communication, and Interdepartmental}

Communication. The means for these communication satisfaction factors show that, in general, employees with the least (fewer than 1 year) and those with the most numbers of years of service (more than 6 years) rated their levels of satisfaction with those communication factors higher than those employees with 1 to 6 years of service.

The Scheffe and Student-Newman-Keuls procedures for Post Hoc Multiple Pairwise Comparisons (Norušis, 1993) showed the following results: First, the employees with fewer than 1 year and more than 6 years of tenure rated their level of communication satisfaction significantly higher $(\mathrm{p}<.001)$ than employees with 1 to 3 years of tenure on the Communication Climate factor. Second, the employees with more than 6 years of tenure rated their level of communication satisfaction significantly higher $(p<.001)$ than employees with 1 to 6 years of tenure on the Horizontal Communication factor. Third, the employees with more than 6 years of tenure rated their level of communication satisfaction significantly higher $(\mathrm{p}<.01)$ than employees with 1 to 3 years of tenure on the Top Management Communication factor. And fourth, the employees with less than 1 year of tenure rated their level of communication satisfaction significantly higher $(\mathrm{p}<.001)$ than employees with 1 more one year of tenure on the Interdepartmental Communication factor.

The results (Table 7) for the school show that, the different groups of tenure were significantly different $(\mathrm{p}<.05$ or more) on their levels of satisfaction on the following communication satisfaction factors: Supervisor Communication, Communication Climate, Top Management Communication, and Interdepartmental Communication. The means for these communication satisfaction factors show that, in general, employees with the least (fewer 
than 1 year) and those with the most numbers of years of service (6 years and more) rated their levels of satisfaction with those communication factors higher than those employees with 1 to 6 years of service.

The Scheffe and Student-Newman-Keuls procedures for Post Hoc Multiple Pairwise Comparisons (Norušis, 1993) showed the following results: First, the employees with fewer than 1 year of tenure rated their level of communication satisfaction significantly higher $(\mathrm{p}<.05)$ than employees with 1 to 3 years of tenure on the Communication Climate and Supervisory Communication factors. Second, the employees with fewer than 1 year of tenure rated their level of communication satisfaction significantly higher $(\mathrm{p}<.01)$ than employees with 1 more one year of tenure on the Top Management Communication and Interdepartmental Communication factors.

The results (Table 7) for the food factory show that, the different groups of tenure were significantly different $(\mathrm{p}<.05)$ on their levels of satisfaction on the following communication satisfaction factors: Horizontal Communication, and Top Management Communication. The means for these communication satisfaction factors show that, in general, employees with the least (fewer than 1 year) and those with the most numbers of years of service (6 years and more) rated their levels of satisfaction with those communication factors higher than those employees with 1 to 6 years of service.

The Scheffe and Student-Newman-Keuls procedures for Post Hoc Multiple Pairwise Comparisons (Norušis, 1993) showed that the employees with more than 6 years of tenure rated their level of communication satisfaction significantly higher $(\mathrm{p}<.05)$ than employees with 1 to 3 years of tenure on the Horizontal Communication and Top Management Communication 
factors.

\section{Comparison of Tenure on Commitment Composites and Factors}

Table 8 reports the results of the Analyses of Variance when tenure and commitment composites were compared for the entire sample and for each organization separately.

The results show that, for the entire sample, the different groups of tenure (employees with fewer than 1 year, employees with 1 to 3 years, employees with 4 to 6 years, employees with more than 6 years) were significantly different $(\mathrm{p}<.05$ or more) on their levels of commitment on the Commitment Composite, and Global Commitment. The means for these commitment composites show that, in general, employees with more than 6 years of service rated their levels of commitment with those commitment composites higher than those employees with fewer than 6 years of service.

The Scheffe and Student-Newman-Keuls procedures for Post Hoc Multiple Pairwise Comparisons (Norušis, 1993) showed that employees with more than 6 years of tenure rated their level of Global Commitment significantly higher $(\mathrm{p}<.001)$ than employees with fewer than 6 years.

For the school, the Scheffe and Student-Newman-Keuls procedures for Post Hoc Multiple Pairwise Comparisons (Norušis, 1993) showed that employees with less than a year of tenure rated the Commitment Composite and the Cook \& Wall Identification factor significantly higher $(\mathrm{p}<.01)$ than employees with 1 to 3 years of tenure. For the food factory, the Scheffe and Student-Newman-Keuls procedures for Post Hoc Multiple Pairwise Comparisons (Norušis, 1993) showed that employees with more than 6 years of tenure rated their level Global Commitment significantly higher $(\mathrm{p}<.001)$ than employees with fewer than 6 years of tenure.No 
significant differences were found for the hospital.

\section{Correlations between Tenure and Communication Satisfaction Factors, and Commitment}

\section{Composites}

No significant correlations were found between tenure and the communication satisfaction factors for the entire sample and for each organization. However, when Pearson Correlations were calculated between tenure and commitment composites for the entire sample and for each organization, the only two significant (p.001) but moderate correlations that emerged were between Tenure and Global Commitment for the entire sample $(r=.24)$ and also for organization $3(\mathrm{r}=.36)$.

\section{Comparison of Supervisors and Subordinates}

Table 9 reports on the results obtained when Paired T-Tests were conducted for the entire sample to discover if supervisors were significantly more satisfied with the communication satisfaction factors than their subordinates. The results indicate that supervisors rated significantly higher (p.<05 or more) than subordinates their levels of communication satisfaction with the following communication satisfaction: Organizational Perspective, Horizontal Communication, Organization Integration, Supervisor Communication, Personal Feedback, and Communication Satisfaction Composite.

On the other hand, a Paired T-Test analysis of the commitment composites and factors by position did not show any significant differences between supervisors and subordinates, although supervisors rated slightly higher on each of the commitment composites. 


\section{CONCLUSIONS AND DISCUSSION}

There are seven major conclusions drawn from these results that will be discussed. These conclusions and discussion are presented following the order of research questions.

First, there was a moderate relationship between communication satisfaction and organizational commitment. The nature of this relationship, however, varied for the communication satisfaction factors and composite, and for the commitment composites and factors.

This study found that there was a positive but moderate relationship between communication satisfaction and organizational commitment. Clearly, this finding is congruent with previous research (Putti, Aryee \& Phua, 1990; Potvin, 1991; Down, 1991; and C. W. Downs et al., 1995).

A comparison of the findings in these studies revealed some interesting similarities and differences among countries (C. W. Downs et al., 1995): First, the Communication Climate factor was the only communication satisfaction factor that was among the ones that had the highest correlations across all countries. Second, the correlation between commitment and satisfaction with Supervisory Communication that was one of the most important links in the USA and Australia, did not exist in Guatemala. For the Guatemalan employees the communication satisfaction factors that had the strongest correlations were: Subordinate Communication, Organizational Integration, Communication Climate, and Interdepartmental Communication. Another important difference was that the Guatemalan employees had the lowest coefficient correlations between the communication satisfaction factors and the Cook 
\&Wall composite. Moreover, it is interesting to note that the communication factors correlated consistently higher with the Mowday, Porter, \&Steers composite than with the Cook \&Wall composite for the Guatemalan employees.

Cultural differences, differences in management style, the type of organization, and specific conditions of the organizations when the studies were conducted, may explain these differences between the Guatemalan employees and the USA Americans and Australians.

The link between communication and commitment for the Guatemalan employees was confirmed by the results obtained when first, more satisfied and less satisfied were compared on commitment composites and factors for Organization 3 (Table 2); and second, more committed employees and less committed employees were compared on the communication satisfaction factors using the entire sample (Table 3). The findings showed that the more satisfied employees are with communication the more committed they are to the organization and vice versa.

Second, overall communication satisfaction showed some prediction power over organizational commitment, although, few communication satisfaction factors emerged as good predictors of organizational commitment. The communication satisfaction composite significantly predicted all the commitment composites used in this study (Table 4). The most frequent communication predictors of commitment were Organizational Integration and Horizontal Communication. The other communication factors that appeared as significant predictors of commitment composites and factors were: Media Quality, Supervisor Communication, Organizational Perspective, Communication Climate, and Interdepartmental Communication. These findings seem to indicate that for the Guatemalan employees the most influential communication practices on their commitment are those related to job requirements, 
departmental plans, personal news, and communication with coworkers. These features should be stressed in management strategies in Guatemalan organizations.

On the other hand, it is interesting to note that these findings present some similarities and differences with the ones reported by C. W. Downs et. al. (1995). They report that Supervisory Communication emerged as a much greater predictor than that of any other factor. However, in this study, Supervisory Communication was not a strong predictor. Moreover, Organization Integration that emerged as the most frequent predictor of commitment in this study, was not as important in the USA and Australian studies. Horizontal Communication, however, appeared as a frequent predictor in all the studies. Other differences were regarding Communication Climate and Top Management that emerged as frequent predictors in the USA and Australian studies, but did not do so in this study. On the contrary, Media Quality, Interdepartmental Communication, and Organization Perspective were factors that emerged as predictors in this study, but did not do so in others. As stated before, cultural differences, differences in management style, the type of organization, and specific conditions of the organizations when the studies were conducted, may explain these differences between the Guatemalan employees and the Americans and Australians.

\section{Third, school teachers were significantly more satisfied with communication and} more committed to their organization than were the employees of a hospital and a food

factory. These findings revealed some interesting differences among the three organizations. Indeed, school teachers were significantly more satisfied with all the communication satisfaction factors and composite, and with commitment composites than the employees of the other two organizations. It is interesting to note, however, that these differences were greater for 
communication satisfaction than for organizational commitment. In fact, school teachers were the only ones who rated all the communication satisfaction factors above 5 (Table 5). In terms of similarities and differences on the communication satisfaction factors, Guatemalan teachers were significantly more satisfied than the employees of the other two organizations on: Organizational Perspective, Organizational Integration, Horizontal Communication, Media Quality factors. On the other hand, the difference on commitment composites and factors among organizations although significant was not large (Table 6).

These findings represent an interesting contribution to the research that has been done on communication satisfaction and organizational commitment, since is the first study that has compared a educational institution to other type organizations. Although several studies (Nicholson, 1980; Jones, 1981; Duke, 1981; Wippich, B., 1983; Wippich, M., 1983) have investigated school teachers' communication satisfaction, none of them reported comparative findings with others type of organizations, such as nursing or manufacturing organizations.

However, the findings of these USA studies present some interesting similarities with the findings of this Guatemala study. On one hand, Supervisor Communication and Organizational Integration were the communication satisfaction that emerged as the ones with which school teachers tend to be most satisfied. On the other, Personal Feedback was the factor that emerged as the one with which school teachers tend to be the least satisfied.

Many factors may account for this difference between school teachers and the employees of the Hospital and Food Factory. One that can be singled out was management style. The teachers of this catholic school (Elementary and High School) were provided with all kind of motivational programs that emphasize good communication practices and a strong sense of 
commitment to the mission. In this school, administrative meetings were conducted

systematically, written information was regularly distributed through different channels, motivational retreats were held at least twice during the academic years. These management strategies, however, were not implemented with the same frequency and intensity in the other two organizations (Hospital and Food Factory). Further research is needed to see whether these similarities and differences hold with other samples of teachers. A hint that we might expect this to be the case can be seen in a study by Whaley \& Hegstrom (1992) which looked at principal communication. They found higher job satisfaction among teachers, and higher satisfaction with "communication of mission," a variable similar to organizational commitment which has been explored here.

Fourth, there were some significant differences on communication satisfaction and organizational commitment by tenure for the Guatemalan employees. The results revealed that, those employees with the least and those with the most years of service were significantly more satisfied with the following communication satisfaction factors: Organizational Climate, Horizontal Communication, Top Management, Interdepartmental Communication, and Supervisory Communication. This finding, however, did not apply to Organization 2 (Hospital), where no two groups were significantly different on communication satisfaction (Table 7).

Employees with more tenure were more committed to their organizations for the food factory. However, for the school, the teachers with fewer than 1 year of service were the most committed (Table 8).

\section{Implications}


These findings seem to suggest that the Guatemalan employees’ communication satisfaction and organizational commitment experienced a process that goes through three different stages: First, the "honeymoon stage" that starts when first entering the organization and may last for 1 year. During this period the levels of communication satisfaction and commitment tend to be high. Second, the "crisis stage" that may start in the second year and last for five or six years. The levels of communication satisfaction and organizational commitment decrease during this period. And third, the "normal stage" that seems to occur after the six year of service in the organization. In this stage the levels of communication satisfaction and commitment tend to increase again. The concept of commitment consistent with these findings was first suggested by Barge \& Schlueter (1988) who claimed that the traditional approaches to commitment have emphasized the conception of commitment as a state of being, and that a process model might be more explanatory. On the other hand, no indication has been found on other studies as to the possibility that communication satisfaction may experience a similar process.

The present study is the one that reports some significant findings on the relationship between tenure and these two organizational variables: communication satisfaction and organizational commitment. This clearly indicates that more research is needed to develop some theoretical understanding on the relationship between these organizational variables.

Fifth, supervisors of the three Guatemalan organizations were more satisfied with communication than subordinates, but similar in their levels of overall commitment to their organizations. Guatemalan supervisors were significantly more satisfied than were subordinates with their overall communication satisfaction and with the following communication satisfaction factors: Organizational Perspective, Personal Feedback, 
Organizational Integration, Horizontal Communication and Supervisory Communication (Table 9).

In terms of communication satisfaction these findings confirmed earlier studies results (Clampitt \& C. W. Downs, 1987) that reported that there appears to be some indication that employees in managerial roles are more satisfied with communication than those who are not. Supervisors were also reported as being more satisfied with communication than with subordinates in a previous study done in Guatemala (Varona, 1988).

The findings of this study also corroborated the findings reported by earlier studies on organizational commitment. Potvin (1991) and Downs (1991) concluded that no significant differences on commitment levels were uncovered for supervisors versus subordinates. C. W. Downs et al. (1995) cross cultural study, did not report any significant difference between supervisors and subordinates on organizational commitment.

Sixth, the three factor solution for the Cook and Wall Organizational Communication Instrument did not emerge, as it had been theorized by its authors, from this sample. However, a three factor solution did surface but with a different structure of factors. Furthermore, a two factor solution for the Mowday, Porter and Steers Organizational Communication Questionnaire emerged as appropriate for the Guatemalan sample.

\section{Reliability and Validity Issues}

A comparison of the findings obtained in this and other studies on the Cronbach Alphas and Factor Analysis of the two commitment instruments suggests the following observations on 
issues related to the validity, internal reliability and the factor solution structure for those instruments.

The high convergent validity of Cook and Wall’s Organizational Commitment Instrument (OCI) found in this study corroborates Downs’ (1991) finding. However, this finding contradicts Barge \& Schlueter's (1988) report which stated that the convergent validity of the instrument had been low.

Another surprising finding in the present study with regard to the Cook \& Wall's instrument was that the commitment composite and theorized factors obtained the lowest Cronbach Alphas (see section on Factor Analysis results). These findings once again contrast with the outcomes of other studies in which the internal reliability of the instrument as a whole and of each factor have proven to be very high (Barge and Schlueter, 1988; Potvin, 1991, and Downs, 1991).

Although a three factor solution did surface for the Cook \& Wall's instrument, the structure of these factors was different from the one that had been theorized by its authors (Cook \& Wall, 1980; Barge \& Schlueter, 1988). Moreover, these outcomes seems to contradict the findings of the Potvin (1991) and Downs (1991) studies which had produced a two factor solution for the Cook \& Wall's instrument.

\section{Mowday, Porter, \& Steers' Organizational Commitment Questionnaire (OCQ)}

In terms of internal reliability and convergent validity for the Mowday, Porter, \& Steers Organizational Commitment Questionnaire (OCQ), the findings of this study were similar to the ones reported by other studies (Mowday, Porter, \& Steers, 1982; Barge \& Schlueter, 1988; Potvin, 1991; Downs, 1991) although not as high (see section on Internal Reliability results). 
Although no factor solution has been theorized by the authors of the Mowday, Porter, \& Steers' (1979) Organizational Commitment Questionnaire (OCQ), a two factor solution emerged for the Guatemala sample (see section on Factor Analysis results). It is interesting to notice that a similar two factor solution for the Mowday, Porter, \&Steers' OCQ also surfaced in the Potvin (1991) study. This finding, to some extent, seem to confirm the theoretical characterization of the instrument as reported by the authors. Mowday, Porter, \& Steers (1979) stated that their instrument is characterized by three dimensions: "(1) a strong belief in and acceptance of the organization's goals and values; (2) a willingness to exert considerable effort on behalf of the organization; and (3) a strong desire to maintain membership in the organization" (p.226). This finding could make an important contribution to the nature and the structure of this instrument that could help in future research by making the findings more specific than they are now without a factor solution.

The conflicting findings, between the studies conducted in the USA and this one conducted in Guatemala , on the internal reliability and factor structure of the Cook \& Wall's Organizational Commitment Instrument, raise several important issues on the use of research instruments in cross-cultural studies.

First, more cross-cultural studies like this are needed to develop a better understanding on the influence that cultural factors, and organizational characteristics may have on the internal reliability and factor structure of research instruments created in a different culture. Second, overall the findings on the commitment instruments both in the USA and in Guatemala clearly indicate that there is a real need for developing more valid and reliable measures of organizational commitment not only for cross-cultural studies but for studies done in the USA. 
Third, the need for more valid and reliable measures of organizational commitment is even greater in light of the findings from the literature review. Up to the present time, a common characteristic of the studies conducted to explore the relationship between communication satisfaction and organizational commitment, is that the communication variable has been constrained to an antecedent condition of commitment. Typically, these studies correlate communication variables to commitment. This approach, according to Barge \& Schlueter (1988) "neglects the communicative nature of commitment and emphasizes the conception of commitment as a state of being versus a process" (p.131). This new conception of commitment as a process was, to some extent, suggested by the findings of this study (see discussion of conclusion fifth). Barge \& Schlueter (1988) suggest that a new theoretical and instrumental departure from current research is needed. This new approach should reconceptualize commitment as a process and incorporate commitment strategies and tactics into organizational commitment measures. Fourth, the need for a new theoretical and instrumental departure from current research on organizational commitment was also stated by Reichers (1985). This author claimed that new measures of organizational commitment need to be developed because the traditional ones have been unable to assess the multidimensionality of this construct in its totality. To overcome these shortcomings, Reichers (1985) suggested a new reconceptualization of the organizational construct which integrates the individual's actual experience of commitment with the organizational aspects of the construct. He argued that organizational commitment can be accurately understood as a collection of multiple commitments to the various groups that comprise the organization. Thus, the complexity of the organizational commitment construct and the need for developing more inclusive conceptualizations and opertionalizations 
of the construct seems apparent.

In sum, although a start has been made, the dearth of cross-cultural research on these issues makes it very difficult to draw global conclusions about these two constructs. Further multinational research is needed to see whether the findings of this study hold with other samples of similar organizations in Latin American countries and in other countries and cultures around the world. Tentatively, this research suggests that cultural differences influence communication and commitment in the workplace. Therefore, the need for more cross-cultural research is an imperative. 


\section{REFERENCES}

Ady, J. C. (1994). Minimizing threats to the validity of cross-cultural organization research. In R.L. Wiseman \& R. Shuter (Eds.) Communicating in multinational organizations (pp. 3042). Thousand Oaks, CA: Sage Publications.

Alum, C. V. (1982). A case study of communication satisfaction in Nova de Monterrey. Unpublished master's thesis. University of Kansas. Lawrence, KS.

Angle, H. L., \& Perry, J. L. (1981). An empirical assessment of organizational communication and organizational effectiveness. Administrative Science Quarterly, 26, 1-14.

Barge, J. K., \& Schlueter, D. W. (1988). A critical evaluation of organizational commitment and identification. Management Communication Quarterly, 2(1), 116-133.

Blau, P. M., \& Scott, W. R. (1962). Formal organizations: A Comparative approach. San Francisco: Chandler.

Buchanan, Bruce II. (1974). Building organizational commitment: The socialization of work managers in work organizations. Administrative Science Quarterly, 19, 533-546.

Clampitt, P. G., \& Downs, C. W. (1993). Employee perceptions of the relationship between communication and productivity. Journal of Business Communication, 30(1), 5-28.

Clampitt, P. G., \& Girard, D. M. (1987 May). Time for reflection: A factor analytic study of the communication satisfaction instrument. Paper presented to the International Communication Association, Montreal, Canada.

Clampitt, P. G., \& Girard, D. M. (Fall 1993). Communication satisfaction: A useful construct? New Jersey Journal of Communication, 1(2), 84-102.

Clampitt, P. G., \& Downs, C. W. (1987). Communication satisfaction: A review of the literature. 
Unpublished paper, University of Kansas, Lawrence, KS.

Cook, J., \& Wall, T. (1980). New work attitude measures of trust, organizational commitment and personal need non-fulfillment. Journal of Occupational Psychology, $\underline{53}$, 39-52.

Crino, M. D., \& White, M. C. (1981). Satisfaction in communication: An examination of the Downs-Hazen measure. Psychological Reports, 49, 831-838.

Dornstein, M., \& Matalon, Y. (1989). A comprehensive analysis of the predictors of organizational commitment: A study of voluntary army personnel in Israel. Journal of Vocational Behavior, 34, 192-203.

Downs, A. (1991). A case study of the relationship between communication satisfaction and organizational commitment in two Australian organizations. Unpublished master's thesis, University of Kansas, Lawrence, KS.

Downs, C.W. (1977). The relationship between communication and job satisfaction. In R.C. Huseman, C.M. Logue, \& S.L. Freshly (Eds.), Readings in interpersonal and organizational communication (pp. 363-376). Boston, Mass.: Holbrook Press.

Downs, C. W. (1988). Communication audits. Glenview, IL: Scott Foresman.

Downs, C. W. (1990). Communication Audit Questionnaire. Unpublished manuscript, University of Kansas, Lawrence, KS.

Downs, C.W., Clampitt, P., \& Pfeiffer, A. (1988). Communication and organizational outcomes. In G. Goldhaber \& G. Barnett (Eds.), Handbook of organizational communication (pp. 171-211). Norwood, NJ:Ablex.

Downs, C.W., Downs, A., Potvin, T., Varona, F., Gribas, J.S., \& Ticehurst, W. (1995). A crosscultural comparison of relationships between organizational commitment and 
organizational communication. Paper presented at the International Communication Association Convention, Albuquerque, NM.

Downs, C. W., \& Hazen, M. D. (1977). A factor analytic study of communication satisfaction. Journal of Business Communication, 14(3), 63-74.

Duke, P. O. (1981). Communication satisfaction of business education teachers in an urban $\underline{\text { school }}$ system. Unpublished doctoral dissertation, Vanderbilt University, Nashville, TN. Eisenberg, E. M., Monge, P. R. \& Miller, K. I. (1983). Involvement in communication networks as a predictor of organizational commitment. Human Communication Research, $\underline{10}(2), 179-201$.

Gouldner, A. W. (1957). Cosmopolitans and locals: Toward an analysis of latent social roles-I. Administrative Science Quarterly, 2, 281-306.

Greenbaum, H., Clampitt, P., \& Willhnganz, S. (November 1988). Organizational communication: An examination of four instruments. Management Communication Quarterly, 2(2), 245-282.

Hall, R. H. (1977). Organizations: Structure and process. Englewood Cliffs, NJ: Prentice-Hall. Hecht, M L. (1978). Measures of communication satisfaction. Human Communication Research, 4, 350-368.

Hofstede, G. (1980). Culture's consequences. Internal differences in work-related values. Beverly Hills, CA: Sage Publications.

Housel, T. J., \& Warren, E. D. (1977). The reduction of upward communication distortion. Journal of Business Communication, (Summer), 49-55. (Argyris' study was reported in 
this article)

Jones, J. W. (1981). Analysis of communication satisfaction in four rural school system. Unpublished doctoral dissertation, Vanderbilt University, Nashville, TN.

Johnson, J. D., \& Tuttle, F. (1989). Problems in intercultural research. In M.K. Asante. \& W.B. Gudykunst (Eds.), Handbook of International and Intercultural Communication (pp 461-483). Newbury Park, C.A.: Sage Publications.

Kio, J.B.A. (1979). A descriptive study of communication satisfaction, need satisfaction, and need importance index among Nigerian workers. Unpublished doctoral dissertation, University of Kansas, Lawrence, KS.

Larson, E., \& Fukami, C. (1984). Relationships between worker behavior and commitment to theorganization and union. Proceedings of the Academy of Management, 1984, 222-226.

Lee, Y. (1989). A study of the relationship between communication and job satisfaction among faculty at the junior colleges of technology in republic of China. Unpublished doctoral dissertation, Drake University, De Moins, IA.

Leiter, M. P. , \& Maslach, C. (1988). The impact of interpersonal environment on burnout and organizational commitment. Journal of Organizational Behavior, $\underline{9}(4)$, 297-308.

Morris, J. H., \& Sherman, J. D. (1981). Generalizability of an organizational commitment model. Academy of Management Journal, 24 (3), 512-526.

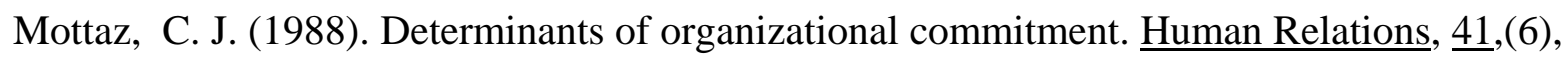
467-482.

Mowday, R. T., Porter, L. W., \& Dubin, R. (1974). Unit performance, situational factors, and employee attitudes in spatially separated work units. Organizational Behavior and 
Human Performance, 12, 231-248.

Mowday, R. T., Porter, L. W., \& Steers, R. M. (1979). The measurement of organizational commitment. Journal of Vocational Behavior, 14, 224-247.

Mowday, R. T., Porter, L. W., \& Steers, R. M. (1982). Employee-organizational linkages: The psychology of commitment, absenteeism, and turnover. New York:Academic Press.

Morrow, P. C. (1983). Concept redundancy in organizational research : The case of work commitment. Academy of Management Review, $\underline{8}(3), 486-500$.

Nicholson, J. (1980). Analysis of communication satisfaction in an urban school system. Unpublished doctoral dissertation, Vanderbilt University, Nashville, TN.

Norušis, M.J. (1993). SPSS for windows: Base system user's guide, release 6.0. Chicago: SPSS Inc.

Porter, L. W., Steers, R. M., Mowday, R. T., \& Boulian, P. V. (1974). Organizational commitment, job satisfaction and turnover among psychiatric technicians. Journal of Applied Psychology, 95(5), 603-609.

Potvin, T. C. (1991). Employee organizational commitment: An examination of its relationship to communication satisfaction and evaluation of questionnaires designed to measure the construct. Unpublished doctoral dissertation, University of Kansas, Lawrence, KS.

Putti, J. M., Aryee, S., \& Phua, J. (1990). Communication relationship satisfaction and organizational commitment. Group \& Organizational Studies, $\underline{15}$ (1), 44-52.

Reichers, A. E. (1985). A review and reconceptualization of organizational commitment. Academy of Management Review, 10(3), 465-476.

Shuter, R. \& Wiseman, R. L. (1994). Communication in multinational organizations. 
Conceptual, theoretical, and practical issues. In R.L. Wiseman \& R. Shuter (Eds.), Communicating in multinational organizations (pp. 3-11). Thousand Oaks, CA: Sage Publications.

Steers, R. M. (1977). Antecedents and outcomes of organizational commitment. Administrative Science Quarterly, 22, 46-56.

Varona, F. (1988). A comparative study of communication satisfaction in two Guatemalan companies. Unpublished master's thesis, University of Kansas, Lawrence, KS.

Varona, F. (1993). Communication satisfaction and organizational commitment: a study in three Guatemalan organizations. Ann Arbor, MI:U.M.I.

Whaley, K. W. \& Hegstrom, T. G. (1992). Perceptions of school principal communication effectiveness and teacher satisfaction on the job. Journal of Research and Development in Education, 25, 224-231.

Wippich, B. (1983). An analysis of communication and job satisfaction in an educational setting. Unpublished doctoral dissertation, University of Kansas, Lawrence, KS.

Wippich, M. L. (1983). Communication satisfaction, communicator style, and perceive organizational effectiveness in an educational setting. Unpublished doctoral dissertation, University of Kansas, Lawrence, KS. 
TABLES

Table 1: Correlation between Communication Satisfaction Factors and Composite, and Organizational Commitment Composites for Organization 3 (Food Factory)

Communication

Factors

Organizational Perspective

Personal Feedback

Organizational Integration

Supervisory Communication

Communication Climate

Horizontal Communication

Media Quality

Subordinate Communication

Top Management Communication Interdepartmental Communication.

Communication Satisf. Composite
Commit.

Composite

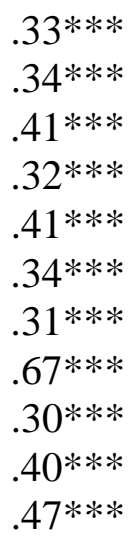

$.33 * * *$

$.41 * * *$

$.32 * * *$

$.41 * * *$

$.34 * * *$

$.31 * * *$

$.67 * * *$

$.30 * * *$

$.47 * * *$
M.P.\& S.

Composite

$.24 * *$

$.32 * * *$

$.43 * * *$

$.37 * * *$

$.41 * * *$

$.31 * * *$

$.36 * * *$

$.60 * * *$

$.31 * * *$

$.41 * * *$

$.46 * * *$
C.\& W.

Composite

$.25^{* *}$
$.22^{* *}$
$.27^{* *}$
.16
$.22^{* *}$
$.26^{* *}$
$.21^{*}$
$.42^{*}$
.13
$.24^{* *}$
$.28^{* *}$

\footnotetext{
$*$ Significant at $\mathrm{p}<0.05$ level

$* *=$ Significant at $\mathrm{p}<0.01$ level

$* * *=$ Significant at $\mathrm{p}<0.001$ level
}

Table 2: Comparison of Less Satisfied Versus More Satisfied Employees on Commitment Composites and Factors for Organization 3 (Food Factory)

Factors

Commit. Composite

MP\&S Composite

$\mathrm{C} \& \mathrm{~W}$ Loyalty

C\&W Identification

$\mathrm{C} \& \mathrm{~W}$ Involvement

$\mathrm{C} \& W$ Composite

Global Commitment
Satisfaction Means

1

Less Satisf. More Satisf.

$(\mathbf{n}=71) \quad(n=70)$

Note: $\mathrm{MP} \& S=$ Mowday, Porter, \& Steers

$\mathrm{C} \& \mathrm{~W}=$ Cook and Wall

5.00

4.96

4.16

5.31

5.36

4.94

4.83
5.48

5.48

4.41

5.79

5.91

5.38

5.57
$\mathbf{F}$

$\mathbf{P}$
$21.67 \quad .001$

$17.90 \quad .001$

$1.31 \quad .25$

$6.49 \quad .01$

$7.46 \quad .001$

$9.39 \quad .001$

$2.23 \quad .001$

Note: MP\&S = Mowday, Porter, \& Steers 
Table 3: Comparison of Less Committed Versus More Committed Employees on Communication Satisfaction Factors and Composite. Entire Sample

\section{Commitment Means}

\begin{tabular}{|c|c|c|c|c|}
\hline Factors & $\begin{array}{c}1 \\
\text { Less } \\
(n=119)\end{array}$ & $\begin{array}{c}2 \\
\text { More } \\
(n=171)\end{array}$ & $\mathbf{F}$ & $\mathbf{p}$ \\
\hline Organizational Perspective & 4.29 & 4.88 & 15.09 & .001 \\
\hline Personal Feedback & 4.75 & 5.03 & 4.25 & .04 \\
\hline Organizational Integration & 4.95 & 5.25 & 6.17 & .01 \\
\hline Supervisory Communication & 5.17 & 5.47 & 3.87 & .05 \\
\hline Communication Climate & 4.69 & 5.08 & 7.49 & .001 \\
\hline Horizontal Communication & 4.72 & 5.09 & 9.41 & .001 \\
\hline Media Quality & 4.73 & 5.03 & 3.99 & .04 \\
\hline Subordinate Communication & 5.28 & 5.46 & .22 & .63 \\
\hline Top Management Communication & 4.63 & 5.03 & 5.66 & .01 \\
\hline Interdepartmental Communication & 4.72 & 5.01 & 3.95 & .04 \\
\hline Comm. Satisfaction Composite & 4.76 & 5.10 & 9.33 & .001 \\
\hline
\end{tabular}

Table 4: Stepwise Multiple Regression (Using Organization 3 Sample and Entire Sample): All Communication Satisfaction Factors, Excluding Subordinate Communication on Commitment Composites, and Factors

\begin{tabular}{|c|c|c|c|c|}
\hline Commitment & CAQ Factors & Mult. R & $\mathbf{F}$ & Signif. \\
\hline Composites & Predictors & & & \\
\hline Organization 3 (Foc & od Factory) & & & \\
\hline MP\&S Composite & Media Quality & & & \\
\hline & Organizational Integration & & & \\
\hline & Supervisory Communication & .53 & 16.13 & .001 \\
\hline C\&W Composite & Horizontal Communication & & & \\
\hline & Organizational Integration & .30 & 13.10 & .001 \\
\hline C\&W Identificat. & Organizational Integration & .30 & 12.39 & .001 \\
\hline C\&W Loyalty & Horizontal Communication & .20 & 5.24 & .05 \\
\hline C\&W Involvem. & Organizational Perspective & .27 & 10.51 & .001 \\
\hline Global Commit. & Interdepartmental Comm. & .22 & 6.78 & .001 \\
\hline Global Commit. & Comm. Satisfaction Composite & .24 & 7.78 & .001 \\
\hline MP\&S Composite & Comm. Satisfaction Composite & .48 & 39.37 & .001 \\
\hline $\begin{array}{l}\text { C\&W Composite } \\
\text { Entire Sample }\end{array}$ & Comm. Satisfaction Composite & .31 & 13.45 & .001 \\
\hline Global Commit. & Horizontal Communication. & & & \\
\hline & Organizational Perspective & .24 & 8.99 & .001 \\
\hline & Comm. Satisfaction Composite & .23 & 16.46 & .001 \\
\hline
\end{tabular}

Note: $\mathrm{MP} \& \mathrm{~S}=$ Mowday, Porter, $\&$ Steers $\mathrm{C} \& \mathrm{~W}=$ Cook and Wall 
Table 5: Comparison of Organizations on Communication Satisfaction Factors: Entire Sample

Factors

Organizational Perspective

Personal Feedback

Organizational Integration

Supervisory Communication

Organizational Climate

Horizontal Communication

Media Quality

Subordinate Communication

Top Management Communication

Interdepartmental Communication

Comm. Satisfaction Composite

\begin{tabular}{ccccl}
\multicolumn{6}{c}{ Organization Means } & F & P \\
$\mathbf{1}$ & $\mathbf{2}$ & $\mathbf{3}$ & & \\
$\mathbf{n}=\mathbf{8 6})(\mathbf{n}=\mathbf{4 6})(\mathbf{n}=\mathbf{1 7 4})$ & & \\
5.28 & 4.30 & 4.34 & 20.68 & .001 \\
5.15 & 4.57 & 4.91 & 3.81 & .02 \\
5.49 & 4.87 & 5.10 & 8.26 & .001 \\
5.65 & 5.26 & 5.25 & 3.04 & .04 \\
5.22 & 4.71 & 4.85 & 3.63 & .02 \\
5.36 & 4.81 & 4.79 & 9.86 & .001 \\
5.29 & 4.69 & 4.75 & 6.05 & .001 \\
5.73 & 5.01 & 5.54 & 1.23 & .29 \\
5.23 & 4.62 & 4.73 & 4.33 & .01 \\
5.03 & 5.18 & 4.74 & 3.17 & .04 \\
5.03 & 4.77 & 4.88 & 8.44 & .001
\end{tabular}

Table 6: Comparison of Organizations on Commitment Composites: Entire Sample

Factors

Commit. Composite

MP\&S Composite

$\mathrm{C} \& W$ Composite

C\&W Identification

C\&W Loyalty

C\&W Involvement

Global Commitment

\begin{tabular}{ccccccc}
\multicolumn{2}{c}{ Organizations } & Means & $\mathbf{F}$ & $\mathbf{P}$ & \\
$\mathbf{1}$ & $\mathbf{2}$ & $\mathbf{3}$ & & & \\
$\mathbf{( n = 8 6 )}$ & $\mathbf{( n = 4 6 )}$ & $\mathbf{( n = 1 7 5 )}$ & & & \\
5.49 & 5.22 & 5.22 & 6.51 & .001 & \\
5.26 & 5.18 & 5.18 & .29 & .74 & \\
5.62 & 5.26 & 5.12 & 11.48 & .001 & \\
6.06 & 5.64 & 5.45 & 10.00 & .001 & \\
& 4.51 & 4.46 & 4.30 & .92 & .39 \\
6.28 & 5.67 & 5.57 & 13.06 & .001 & \\
5.94 & 4.78 & 5.13 & 17.53 & .001 &
\end{tabular}

Note: $\mathrm{MP} \& S=$ Mowday, Porter, \& Steers

$\mathrm{C} \& \mathrm{~W}=$ Cook and Wall 
Table 7: Comparison of Tenure on the Communication Satisfaction Factors. Entire Sample, Organization 1 (School), and Organization 3 (Food Factory)

Entire Sample:

Factors

Horizontal Communication

Top Management Communication

Interdepartmental Communication
Communication Climate

\begin{tabular}{|c|c|c|c|c|c|}
\hline \multicolumn{4}{|c|}{ Tenure Means } & \multirow[t]{2}{*}{$\mathbf{F}$} & \multirow[t]{2}{*}{$\mathbf{P}$} \\
\hline 1 & 2 & 3 & 4 & & \\
\hline Years & $\begin{array}{l}<1 \\
(n=54)\end{array}$ & $\begin{array}{c}1-3 \\
(n=103\end{array}$ & $\begin{array}{c}4-6>6 \\
(n=57)(n=92)\end{array}$ & & \\
\hline & 5.26 & 4.72 & 4.705 .13 & 4.02 & .001 \\
\hline & 5.06 & 4.72 & 4.825 .24 & 4.65 & .001 \\
\hline & 5.15 & 4.54 & 4.765 .09 & 3.40 & .01 \\
\hline & 5.39 & 4.75 & 4.554 .97 & 5.26 & .001 \\
\hline
\end{tabular}

Organization 1 (School):

Factors

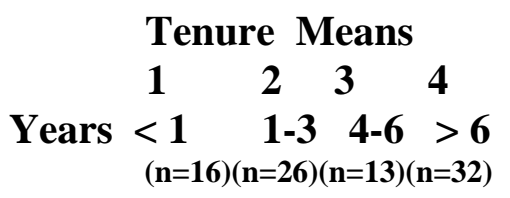

Supervisory Communication.

$\begin{array}{llll}6.11 & 5.25 & 5.84 & 5.66\end{array}$

$\begin{array}{llll}5.77 & 4.81 & 5.27 & 5.25\end{array}$

$\begin{array}{llll}6.00 & 5.00 & 4.91 & 5.16\end{array}$

$\begin{array}{llll}5.88 & 4.69 & 4.43 \quad 5.10\end{array}$

F $\quad \mathbf{P}$

Communication Climate

Top Management Communication

Interdepartmental Communication

Organization 3 (Food Factory):

\begin{tabular}{|c|c|c|c|c|c|}
\hline \multirow[t]{3}{*}{ Factors } & \multicolumn{3}{|c|}{ Tenure Means } & \multirow[t]{2}{*}{$\mathbf{F}$} & \multirow[t]{3}{*}{$\mathbf{P}$} \\
\hline & 1 & 23 & 4 & & \\
\hline & $\underset{(n=18)}{1}$ & $\begin{array}{cc}1-3 \quad 4-6 \\
(n=63)(n=37)\end{array}$ & $\begin{array}{c}>6 \\
(n=59)\end{array}$ & & \\
\hline Horizontal Communication & 4.97 & 4.524 .72 & 5.07 & 3.11 & .02 \\
\hline Top Management Communication & 5.23 & 4.334 .66 & 5.04 & 2.77 & .04 \\
\hline
\end{tabular}


Table 8: Comparison of Tenure on Global Commitment and Commitment Composite for Entire Sample, Organization 1 (School), and Organization 3 (Food Factory)

Composites

$$
\begin{aligned}
& \text { Tenure Means } \quad \text { F } \quad \text { P } \\
& \begin{array}{llll}
1 & 2 & 3 & 4
\end{array} \\
& \text { Years }<1 \quad 1-3 \quad 4-6>6 \\
& (n=52)(n=104)(n=56)(n=86)
\end{aligned}
$$

Entire Sample:

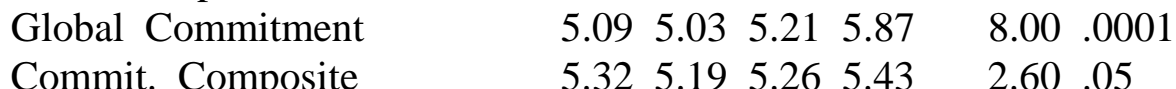

\begin{tabular}{|c|c|c|c|c|c|}
\hline \multirow[t]{4}{*}{ Composite } & \multicolumn{4}{|c|}{ Tenure Means } & \multirow[t]{4}{*}{$\mathbf{F}$} \\
\hline & 1 & 2 & 3 & 4 & \\
\hline & Years $<1$ & $1-3$ & 4-6 & $>6$ & \\
\hline & & $(n=63)($ & $(n=37)($ & $(n=59)$ & \\
\hline Global Commit. & 4. & 54.90 & 5.00 & 5.71 & 5.70 \\
\hline
\end{tabular}

Organization 1 (School):

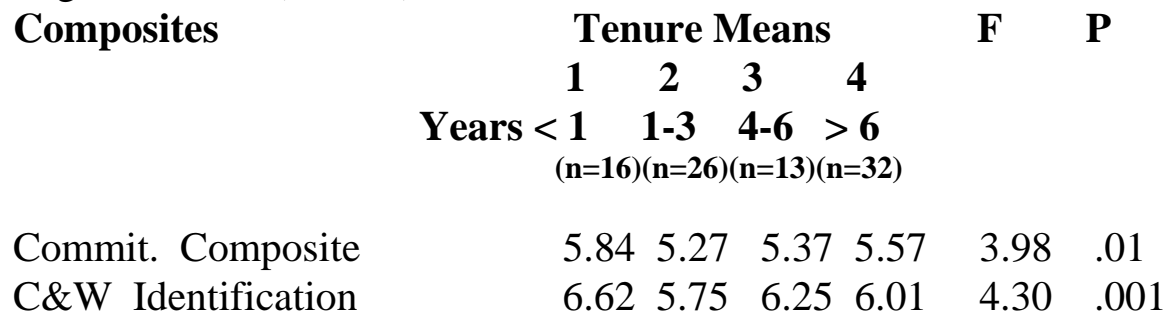

Organization 3 (Factory):

Table 9: Paired T-Tests between Supervisors and Subordinates on Communication Factors for Entire Sample

Variable

Comm. Satisfaction Composite

Organizational Perspective

Personal Feedback

Organizational Integration

Supervisory Communication

Horizontal Communication

$\begin{array}{lllll}\text { Pos. } & \text { Mean } & \text { T. Value } & \text { DF } & \text { Prob. } \\ \text { Sup. } & 5.22 & 2.32 & 83 & .02 \\ \text { Sub. } & 4.91 & & & \\ \text { Sup. } & 4.99 & 2.86 & 86 & .001 \\ \text { Sub. } & 4.52 & & & \\ \text { Sup. } & 5.21 & 2.00 & 79 & .04 \\ \text { Sub. } & 4.87 & & & \\ \text { Sup. } & 5.39 & 2.31 & 89 & .02 \\ \text { Sub. } & 5.07 & & & \\ \text { Sup. } 5.67 & 2.16 & 86 & .03 \\ \text { Sub. } & 5.30 & & & \\ \text { Sup. } & 5.26 & 3.10 & 102 & .001 \\ \text { Sub. } & 4.88 & & & \end{array}$

